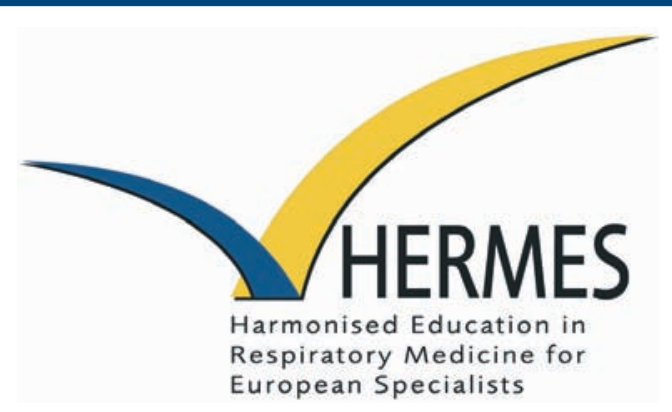

\title{
HERMES: a European Core Syllabus in Respiratory Medicine
}

This task force was approved by the Executive Commitee of the

ERS and endorsed by the UEMS

Section/Board of Pneumology.

R. Loddenkemper,

T. Séverin, J-L. Eiselé,

A. Chuchalin, C.F. Donner,

G. Di Maria, P. Magyar,

M. Muers, J-F. Muir,

B. Nybo, G. Phillips,

G. Riddell, R. Stevenson,

M. Zach, P.L. Haslam

\section{Summary}

HERMES is a project to promote better "Harmonised education and training in Respiratory Medicine for European Specialists". The first aim of the project was to develop a European core syllabus listing core competencies that all respiratory specialists should possess. This report presents the resulting consensus-based document. A total of 50 experts in respiratory medicine from 29 countries took part in its development. Moreover, over 400 qualified respiratory physicians and over 100 trainees provided further feedback throughout the project.

Competencies were identified and ranked through a three-round Delphi consensus process. Some 229 competencies were selected and split into nine sections and 51 modules. Of these, 14 were ranked as optional, 215 as mandatory. Items were further ranked into three different levels, according to the level of knowledge and competence expected. The Delphi process proved an effective tool for creating expert consensus and to enable "group" ownership of the project outcomes.

Over the last few years, free movement within a growing European Union has helped boost a long-identified need for common standards in professional training and qualifications. In medicine, although there is currently no legal basis for a European diploma and examination system, training and certification of specialists in a harmonised framework would constitute an advantage for practising physicians in any European country. Better harmonised training and education programmes would, most likely, result in raising the level of qualification of medical professionals throughout Europe, for the ultimate benefit of the patients.

A benchmark analysis, conducted by this group in 2005 (table 1), revealed that many other medical specialties have already undertaken various attempts to harmonise training and education in their respective fields. The table illustrates a range of initiatives which selected specialties have already implemented over the last 10 years. More detailed information is available in a 2005 European Respiratory Society (ERS) report available at www.ersnet.org/hermes

In the field of respiratory medicine, the first core curriculum was issued in 1994 [1]. It served as a basis for the European Union of Medical Specialists (UEMS) "Chapter 6 Charter on training", which included recommendations for the duration and structure of specialty training, as well as a list of core competencies [2]. Since its publication over a decade ago, this document has not been regularly updated.

In 2005, considering the strong need to harmonise education and training, the ERS launched the HERMES project. This project, which will last an estimated $4-5$ years, aims to

\section{Correspondence:}

$R$. Loddenkemper

Lungenklinik Heckeshorn

Zum Heckeshorn 33

14109 Berlin

Germany

Fax: 493080022435

E-mail: loddheck@zedat.fuberlin.de 


\section{Table $1 \quad$ Activities already implemented by a selection of European scientific societies and/or UEMS Boards}

\begin{tabular}{|c|c|c|c|c|}
\hline \multirow[t]{2}{*}{ European society or board } & \multicolumn{4}{|c|}{ Activity } \\
\hline & $\begin{array}{l}\text { European } \\
\text { syllabus }\end{array}$ & $\begin{array}{l}\text { Approved } \\
\text { training } \\
\text { centres }\end{array}$ & $\begin{array}{c}\text { European } \\
\text { examination }\end{array}$ & References \\
\hline $\begin{array}{l}\text { Paediatric Assembly of the } \\
\text { European Respiratory Society } \\
\text { (ERS) }\end{array}$ & ○ & ○ & & [3] \\
\hline $\begin{array}{l}\text { European Society of } \\
\text { Cardiology (ESC) }\end{array}$ & - & & 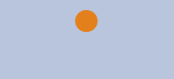 & {$[4,5]$} \\
\hline $\begin{array}{l}\text { European Society for } \\
\text { Emergency Medicine (EUSEM) }\end{array}$ & - & ○ & - & {$[6]$} \\
\hline $\begin{array}{l}\text { European Society of Intensive } \\
\text { Care Medicine (ESICM) }\end{array}$ & - & ○ & - & [7] \\
\hline $\begin{array}{l}\text { European Association of } \\
\text { Neurosurgical Societies (EANS) }\end{array}$ & & & - & [8] \\
\hline $\begin{array}{l}\text { European Society of } \\
\text { Anaesthesiology (ESA) }\end{array}$ & - & & - & {$[9,10]$} \\
\hline $\begin{array}{l}\text { European Society of Medical } \\
\text { Oncology (ESMO) }\end{array}$ & ○ & & $\odot$ & {$[11]$} \\
\hline $\begin{array}{l}\text { European Federation of } \\
\text { Internal Medicine (EFIM) }\end{array}$ & - & & - & \\
\hline $\begin{array}{l}\text { European Board of } \\
\text { Ophthalmology }\end{array}$ & 0 & $\bullet$ & 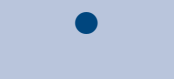 & {$[12]$} \\
\hline $\begin{array}{l}\text { European Board of } \\
\text { Gastroenterology }\end{array}$ & - & - & - & [13] \\
\hline European Board of Urology & 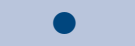 & & ○ & [14] \\
\hline $\begin{array}{l}\text { European Board of Vascular } \\
\text { Surgery }\end{array}$ & 0 & & - & {$[15]$} \\
\hline $\begin{array}{l}\text { European Federation for } \\
\text { Colposcopy }\end{array}$ & ○ & & & {$[16]$} \\
\hline $\begin{array}{l}\text { European Section/Board of } \\
\text { Allergology and Clinical } \\
\text { Immunology }\end{array}$ & ○ & & & {$[17,18]$} \\
\hline
\end{tabular}

: current activities; : future activities. basis for training in their own country or for the development of local requirements.

\section{Methodology}

The benchmark analysis for this project, which was conducted throughout May and June 2005 (table 1), showed that in order to harmonise education and training throughout Europe, it would first be necessary to reach a consensus about a common core syllabus outlining the core skills and competencies any specialist in respiratory medicine should possess.

In light of these findings, consensus development methods and their use in projects similar to HERMES were analysed.

As stated in a report issued by the National Coordinating Centre for Health Technology Assessment (UK), three different consensus techniques are commonly used within the Health sector: 1) the Delphi technique, 2) the Nominal group technique, and 3) the Consensus development conference. Within these three, there was a strong predominance of the Delphi technique for issues related to syllabus/curriculum development [20].

The Delphi technique is an interactive process, designed to lead to a consensus between a panel of pre-selected experts. Using this technique, participants do not meet or interact directly. Instead, they are sent surveys which they are asked to complete. As a rule, experts are initially asked to suggest the items that should be considered by the group. Subsequently, once these items are determined, participants receive a survey which seeks their individual opinions about the items that they and the other participants have proposed. The responses are collated by the organisers and sent back to participants in summary form. Participants can then revise their judgement in light of the group feedback. This process may be repeated a number of times. The judgements of participants are statistically aggregated after each round [21-23].

This method allows large numbers of participants to be surveyed. It, therefore, allows many potential stakeholders to participate and develop a feeling of ownership of the project outcome, which is essential for later integration of the results of the study into practice. A Delphi process with three rounds was identified as the most appropriate method for the production of the core syllabus.

To provide the panel of experts with more food for thought, the Delphi process was modified so that the first two rounds were open not 


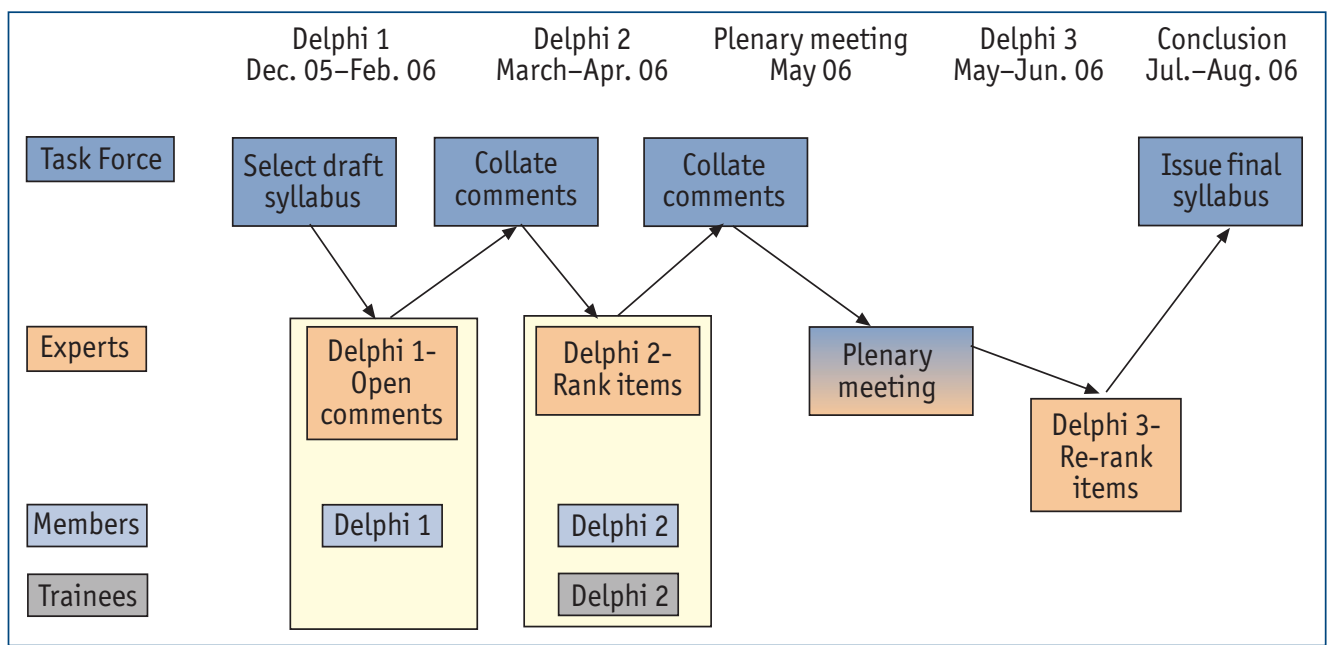

only to the expert national respondents in curriculum development, but also to ERS clinical members qualified in respiratory medicine and to trainees in the specialty to gain wider feedback. However, results from these different groups of respondents were always analysed separately.

Another modification was made to compensate for one of the identified weaknesses of the Delphi technique, which is that it does not allow participants to discuss the issues that were raised nor to elaborate on their views [24]. It was, therefore, decided to include a plenary meeting after the second Delphi round with all task force members and additional national experts, to allow experts to exchange their views before starting the third and last Delphi round.

The project was coordinated by the ERS headquarters and funded by an Educational ERS School Task Force. The panel included a Chair and Co-Chair, four experts representing different European regions, as well as one representative from each of the following organisation: ERS, ERS School, UEMS, European Board for Accreditation in Pneumology (EBAP), Forum of European Respiratory Societies (FERS) and Permanent Working Group of European Junior Doctors (PWG).

In parallel, it was necessary to identify a panel of European experts who would represent each participating country. To that end, the president of each European national respiratory society was contacted and asked to provide the name of an expert in respiratory medicine education. In addition, ERS Assembly Secretaries, who are also members of the ERS School, were asked to represent their Assemblies to ensure that each sub-specialty of respiratory medicine was adequately represented.

Including the task force, national experts and ERS School members, 50 individuals from
29 participating countries were contacted and agreed to participate in the project.

In addition to that core group of respondents, it was decided that the opinion of specialists in adult respiratory medicine from the ERS membership, as well as that of trainees, would be sought. As mentioned above, these data were presented to the task force and group of experts to make them aware of the opinion of other stakeholders. However, the data were not statistically integrated into the data from the experts in the analysis of the different Delphi rounds.

The task force held its first meeting in November 2005, with the aim to draft the first version of the European syllabus. This draft document was put online in December 2005 for the first Delphi round, where participants were asked to review the items proposed by the task force, to comment on them and to add any further items deemed necessary. Data were collected online using survey software (www.surveymonkey.com).

All comments were collated and, during the second meeting in February 2006, these were used by the task force to design the second Delphi round. This survey listed all items included in the updated draft syllabus, and participants

\section{Table 2 Status and levels of competence available as a choice for all items}

Figure 1

Timeline, steps and stakeholders.

$\begin{array}{ll}\begin{array}{l}\text { Status } \\ \text { Optional }\end{array} & \begin{array}{l}\text { It is recommended that this item be included in the core } \\ \text { syllabus but is not mandatory. } \\ \text { It is required that this item be included in all the core syllabi. } \\ \text { Mandatory } \\ \text { Not relevant }\end{array} \\ \begin{array}{l}\text { Competence level } \\ \text { Level 1 } 1\end{array} & \begin{array}{l}\text { Awareness sufficient to recognise and know when to refer. } \\ \text { Level } 2 \\ \text { Level } 3\end{array} \\ & \begin{array}{l}\text { Knowledge sufficient to manage with supervision (or refer). } \\ \text { practice. }\end{array}\end{array}$


were asked to decide upon a status (optional, mandatory or not relevant), as well as a level of competence for each item (table 2).

The responses from this second survey were collated and analysed. As in round one, the results were computed separately for the task force members and national experts, for the ERS membership and for trainees.

A plenary session was organised in May 2006 in Munich, for task force members and additional national experts, to discuss controversial items, allowing for a lively debate and for clarification of some headings that had not been fully understood by all members of the panel.

In light of these discussions, and of the results of the second survey, attendees were asked to complete a final survey for the third Delphi round. The responses from this third survey were again computed.

The task force met in June 2006 in Amsterdam to finalise this document on the basis of the data collected.

\section{Results}

On its first meeting, the task force drafted a syllabus containing 176 items split into seven sections and 47 modules. In round one, 33 experts from 23 countries completed the survey, i.e. a participation rate of $69 \%$ (table 3). Response from task force members in round one was not essential as they produced the survey. For each item proposed by the task force, respondents were asked to state whether they agreed, disagreed or whether the proposed item was not relevant to practice in their country. Out of 176 items proposed by the task force, only 26 , i.e. $14.7 \%$, reached $<80 \%$ agreement. Furthermore, task force members and national experts submitted 105 new items. Respondents from the survey open to ERS membership submitted 208 items. Once both lists were collated, 295 items remained open for discussion. In addition to these suggestions, both groups of respondents submitted 57 and 177 general open comments, respectively. As a result of round one, the draft syllabus was modified to include a total of 225 items split into nine sections and 51 modules (table 3).

In round two, 34 experts from 24 countries responded, i.e. a participation rate of $73 \%$. With regard to the status attributed to each item, within task force members and national experts, 211 items were ranked as mandatory and only 14 as optional (none as 'not relevant'). These figures amounted to 199, 26 and 0 among ERS membership and to 186, 39 and 0 among trainees, respectively. With respect to levels of competence, the task force members and national experts ranked 133 items at level three, 63 at level two and five at level one. These figures amounted to 94, 82 and 25 among ERS membership and to 70,83 and 48 among trainees. However, even among the panel of experts, there was, in many cases, no clear-cut majority.

The plenary meeting, which was held in May, thus allowed all 24 participants who were able to attend to discuss controversial items, and resulted in the renaming of a number of items. All experts present were then asked to complete the third Delphi survey.

Participation reached $86 \%$, with a clear convergence of opinion for most of the items that were discussed during the meeting. Based on these results, the task force met one last time in June to validate the outcomes of the last Delphi round, resulting in the production of the syllabus. Items whose status was considered to be

\section{Table 3 Aggregated answers from the different categories of respondents}

\begin{tabular}{|c|c|c|c|c|c|c|c|c|c|c|}
\hline $\begin{array}{l}\text { Delphi } \\
\text { round }\end{array}$ & Category & Replies & $\begin{array}{l}\text { Items } \\
\text { suggested }\end{array}$ & Comments & Mandatory & Optional & $\begin{array}{c}\text { Not } \\
\text { relevant }\end{array}$ & Level 1 & Level 2 & Level 3 \\
\hline \multirow[t]{4}{*}{ Round 1} & Task Force & 4 & 105 & 57 & $N A$ & $N A$ & $N A$ & $N A$ & $N A$ & $N A$ \\
\hline & Experts & 29 & & & $N A$ & $N A$ & $N A$ & $N A$ & $N A$ & $N A$ \\
\hline & Members & 421 & 208 & 177 & $N A$ & $N A$ & $N A$ & $N A$ & $N A$ & $N A$ \\
\hline & Trainees & 27 & & & $N A$ & $N A$ & $N A$ & $N A$ & $N A$ & $N A$ \\
\hline \multirow[t]{4}{*}{ Round 2} & Task Force & 8 & 3 & 11 & 211 & 14 & 0 & 5 & 63 & 133 \\
\hline & Experts & 26 & 0 & & & & & & & \\
\hline & Members & 311 & 0 & 25 & 199 & 26 & 0 & 25 & 82 & 94 \\
\hline & Trainees & 138 & 0 & 17 & 186 & 39 & 0 & 48 & 83 & 70 \\
\hline \multirow[t]{2}{*}{ Round 3} & Task Force & 6 & 0 & & 215 & 14 & $N A$ & 3 & 53 & 144 \\
\hline & Experts & 13 & 0 & & & & & & & \\
\hline
\end{tabular}


worthy of revision in the near future were marked with $a$ *.

Detailed results of each Delphi round are available on the HERMES website (www.ersnet.org/hermes).

\section{Discussion}

While the practice of adult respiratory medicine may differ between countries, there are undoubtedly a number of core competencies which are, or should be, required from any qualified specialist. The objective of this first part of the HERMES project was to obtain a consensus for this set of core competencies, to define a European Core Syllabus, which might also offer an option to serve as a basis to develop or update national syllabi and training programmes. Furthermore, a strong statement was made that this syllabus should aim at the highest level and at defining where respiratory medicine should stand, as opposed to where it currently stands, thus looking towards the future and not towards the past. In particular, a number of sub-specialties or overlapping specialties, such as oncology, were clearly identified as mandatory. For the future, it is perhaps surprising that the consensus view does not yet regard basic knowledge of certain subjects, such as molecular biology, as mandatory. Clearly an updating mechanism is essential to address any deficiencies or problems that might arise from practice using this version of the core syllabus. A section of the HERMES website will thus be provided for comments from users, which will be used as a basis for futher consensus surveys at 1-2-year intervals.

The levels of competence defined by the syllabus were those that were considered appropriate to trainees nearing the end of their postgraduate specialty training. There was, therefore, a common understanding that, with time and experience, specialists would be able to reach higher levels of competence than those indicated in this core syllabus.

The modified Delphi process, involving a very dedicated panel of experts and anonymous ERS members and young trainees, was not only useful for collecting ideas and suggestions, but it also emphasised the importance and usefulness of the whole project to those involved at all levels. It further enabled a wide consensus to be reached and encouraged individual ownership of the project outcomes from early on.

As stated by Murphy et al. (1998), "the Delphi technique and other consensus

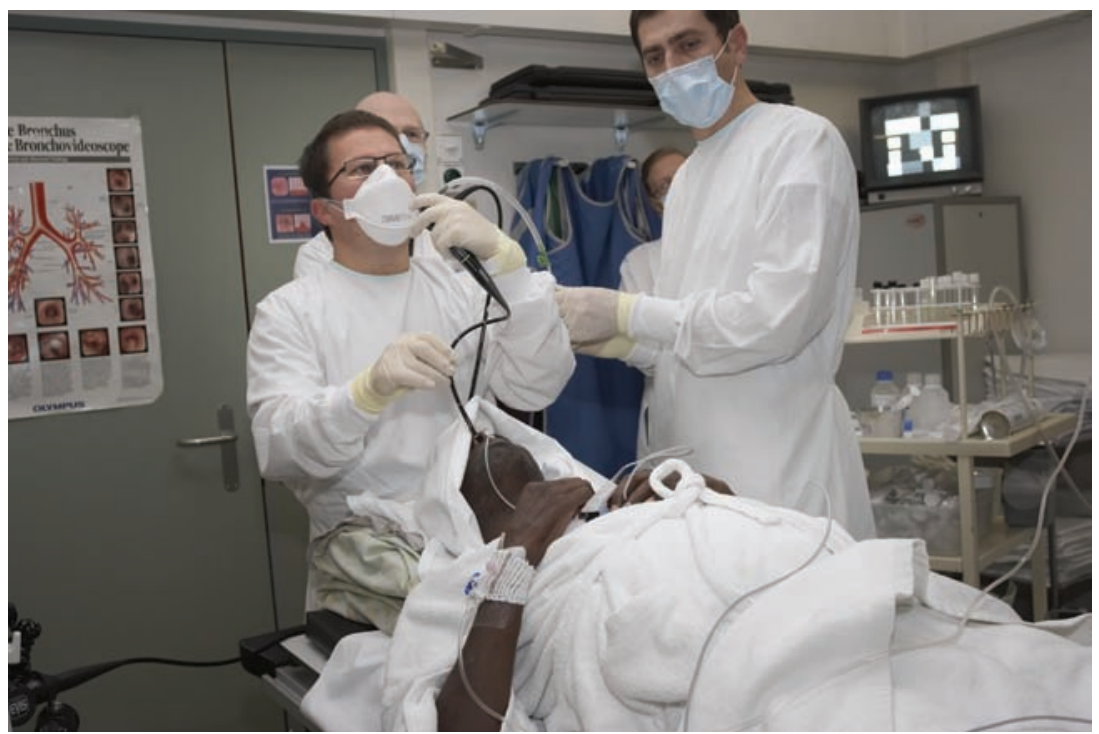

development methods should not be viewed as a scientific method for creating new knowledge, but rather as a process for making the best use of available information, be this scientific data or the collective knowledge of participants". Taking this into account, the Delphi process was modified to better fit needs of the project. The plenary meeting provided compensation for one of the weaknesses of the process. This meeting showed that in a few cases, the experts had divergent opinions because they did not have the same understanding of the item that they were ranking. It should be noted that the syllabus was drafted in English, and that great effort thus had to be made to ensure that the vocabulary used would be understandable by both native and non-native speakers. Furthermore, live discussion allowed for clarifications which encouraged a further convergence of opinions. The live meeting also allowed participants to exchange views regarding the future of the project.

\section{Conclusion}

The now-approved European core syllabus in adult respiratory medicine has been an important first step to guide future developments of the HERMES project, which will include drafting curriculum recommendations (i.e. teaching and assessment methods, training programme, etc.), developing educational materials, assessing training centres and developing a voluntary European examination. The process further created a strong feeling of ownership and a spirit of group collaboration and achievement.

The European Core Syllabus is freely available to all interested parties. Its dissemination will be ensured through the present article in 
Breathe, as well as through the HERMES website (www.ersnet.org/hermes), which further contains a lot of background information regarding the project as a whole. Furthermore, the ERS will encourage translation of the syllabus into other languages to facilitate dissemination, use and acceptance. It is also intended that the syllabus will be updated on a regular basis.

It is hoped through its broad dissemination, this syllabus will foster an increase in harmonisation of education and training throughout Europe, thereby promoting free movement for trainees and experts, and improving the quality of patient care.

\section{Acknowledgements}

The following experts participated in the Delphi process:

A. Altraja3 (Estonia), N. Ambrosino 2 (Italy), J.L.W. Alvarez-Sala3 (Spain), E. Brambilla2 (France), P. Calverley2 (UK), E. Canalis² (Spain), M. Cazzola² (Italy), L. Chovan³ (Slovakia), A. Chuchalin (Russia), R. Cosentini² (Italy), F. de Jongh² (the Netherlands), L. Delaunois 3 (Belgium), G. Di Maria ${ }^{1}$ (Italy), C.F. Donner (Italy), M. Gaga2,3 (Greece), M. Gappa² (Germany), C. Gratziou² (Greece), L. Hansson ${ }^{3}$ (Sweden), P.L. Haslam (UK), P. Hesse ${ }^{3}$ (Austria), Y. Ivanov ${ }^{3}$ (Bulgaria), D. Keser ${ }^{3}$ (Bosnia-Herzegovina), V. Kinnula ${ }^{3}$ (Finland), A. Kocabas ${ }^{3}$ (Turkey), J. Kozielski ${ }^{3}$ (Poland), A. Krams ${ }^{3}$ (Latvia), L. Laursen ${ }^{3}$ (Denmark), R. Loddenkemper ${ }^{1}$ (Germany), P. Magyar ${ }^{1}$ (Hungary), T. McDonnel ${ }^{3}$ (Ireland), F. Mihaltan ${ }^{3}$ (Romania), M. Muers ${ }^{1}$ (UK), J-F. Muir ${ }^{1}$ (France), S. Nava ${ }^{2}$ (Italy), B. Nybo ${ }^{1}$ (Denmark), P. Palange ${ }^{2}$ (Italy), J. Paton ${ }^{2}$ (UK), V. Petrovic ${ }^{3}$ (Serbia and Montenegro), G. Phillips ${ }^{1}$ (UK), N. Rakusic ${ }^{3}$ (Croatia), G. Riddell ${ }^{1}$ (UK), F. Smeenk ${ }^{3}$ (The Netherlands), J. Sorli ${ }^{3}$ (Slovenia), R.J. Sotto-Mayor ${ }^{3}$ (Portugal), R. Stevenson ${ }^{1}$ (UK), G. Sybrecht ${ }^{2}$ (Germany), T. Tollali ${ }^{3}$ (Norway), M. Tamm³ (Switzerland), M. Zach ${ }^{1}$ (Austria), P. Zatloukal ${ }^{3}$ (Czech Republic).

1: Task Force member; 2: ERS School member; 3: National expert.

\section{References}

1. Dijkman JH, Martinez Gonzales del Rio J, Loddenkemper R, Prowse K, Siafakas N. Report of the working party of the "UEMS Monospeciality Section on Pneumology" on training requirements and facilities in Europe. Eur Respir J 1994; 7: 1019-1022.

2. UEMS Charter on Training of Medical Specialists in the EU - Requirements for the specialty Pneumology Union. Brussels, Européenne des Médecins Spécialistes, European Board of Pneumology, 1995.

3. Zach MS, Long Range Planning Committee, Paediatric Assembly of the European Respiratory Society, Committee on Paediatric Respiratory Training in Europe, European Board of Paediatrics. Paediatric respiratory training in Europe: syllabus and centres. Eur Respir J 2002; 20: 1587-1593.

4. Mills P, ESC Education Committee ESC Core Syllabus. A Learning Framework for the Continuing Medical Education of the General Cardiologist. France, European Society of Cardiology, 2004.

5. Di Mario C. ESC Working Group on Interventional Cardiology. Curriculm and Syllabus for Interventional Cardiology Subspeciality Training in Europe. France, European Society of Cardiology, 2006.

6. Manifesto for Emergency Medicine in Europe. Council of the European Society for Emergency Medicine. Eur J Emerg Med 1998; 5: 389-390.

7. Barrett H, Bion JF. An international survey of training in adult intensive care medicine. Intensive Care Med 2005; 31: 553-561.

8. Haase J. The European examination - its present status and potential development. Acta Neurochirurgica Supplementum 2004; 90: 107-114.

9. Simpson P. Training, assessment and accreditation in anaesthesiology and the implications for the European Union. EurJ Anaesthesiol 2003; 20: 679-681.

10. Zorab JSM. The European Diploma in Anaesthesiology and Intensive Care of the European Academy of Anaesthesiology. Acta Anaestesiologica Scandinavica 1995; 39: 579-581.

11. Hansen HH, Bajorin DF, Muss HB, Porkalne G, Schrijvers D, Stahel R. Recommendations for a Global Core Curriculum in Medical Oncology. Ann Oncol 2004; 15: 1603-1612.

12. European Board of Opthalmology. www.ebo-online.org/

13. Beattie AD, Greff M, Lamy V, Mallinson CN. The European Diploma of Gastroenterology: progress towards harmonization of standards. Eur J Gastroenterol Hepatol 1996; 8: 403-406.

14. Ballario $R$, Rubilotta $E$. Training and general and financial conditions of European residents in urology: an international survey. Eur Urol 2004; 46: 517-521.

15. Bergqvist D. The Developing European Board Vascular Examination. Eur J Vasc Endovasc Surg 2004; 27: 339-340.

16. Redman CW, Dollery E, Jordan JA. Development of the European Colposcopy Core Curriculum: use of the Delphi technique. J Obstet Gynaecol 2004; 24: 780-784.

17. Del Giacco SG, Malling HJ. Diversity of allergy and clinical immunology reunified by training at the EU level. Allergy 2004; 59: 575-576.

18. Malling HJ, Gayraud J, Papagergiu-Syxoni P, Hornung B, Rosado-Pinto J, Del Giacco SG. Objectives of training and specialty training core curriculum in allergology and clinical immunology. Allergy 2004; 59: 579-588.

19. Burton JL, McDonald S. Curriculum or syllabus: which are we reforming? Med Teach 2001; 23: 187-191.

20. Murphy MK, Black NA, Lamping DL, et al. Consensus development methods, and their use in clinical guideline development: a review. Health Technol Assess 1998; 2: 1-88.

21. Keeney S, McKenna H. Research guidelines for the Delphi survey technique. J Adv Nurs 2000; 32: 1008-1015.

22. Goodman CM. The Delphi technique: a critique. J Adv Nurs 1987; 12: 729-734.

23. Powell C. The Delphi technique: myths and realities. J Adv Nurs 2003; 41: 376-382.

24. Walker AM, Selfe J. The Delphi method: a useful tool for the allied health researcher. Br J Ther Rehabil 1996; 3: 677-681. 


\section{Table 4 HERMES syllabus}

Module A.1: Structure and function of the respiratory system

A.1.1 Anatomy

A.1.2 Development and ageing of respiratory system

A.1.3 Physiology

A.1.4 Pathophysiology

A.1.5 Microbiology

A.1.6 Genetics

A.1.7 Pharmacology

A.1.8 Pathology

A.1.9 Immunology and defence mechanisms

A.1.10 Molecular biology

A.1.11 Biochemistry

See also modules: I

\section{Module B.1: Airway diseases}

\section{B.1.1 Asthma}

B.1.2 Acute bronchitis

B.1.3 Chronic bronchitis

B.1.4 COPD (chronic obstructive bronchitis and/or emphysema)

B.1.5 Bronchiolitis

B.1.6 Bronchiectasis

B.1.7 Airway stenosis and malacia

B.1.8 Tracheo-oesophageal fistula

B.1.9 Upper airway disease

B.1.10 Vocal cord dysfunction

B.1.11 Foreign body aspiration

B.1.12 Gastro-oesophageal reflux

See also modules: B.2, B.4, B.5, B.6, B.8, B.9, B.10, B.14, B.15, B.16, B.17, B.18,

B.19, B.20, B.21

\section{Module B.2: Thoracic tumours}

\section{B.2.1 Lung cancer}

B.2.2 Metastatic pulmonary tumours

B.2.3 Mesothelioma

B.2.4 Metastatic and other pleural tumours

B.2.5 Benign intra-thoracic tumours

B.2.6 Mediastinal tumours

B.2.7 Chest wall tumours

B.2.8 Sarcoma

B.2.9 Lymphoma

See also modules: B.1, B.6, B11, B.12, B.13, B.14

Module B.3: Non-TB respiratory infections

B.3.1 Upper respiratory tract infections

B.3.2 Lower respiratory tract infections

B.3.3 Community-acquired pneumonia

B.3.4 Nosocomial pneumonia

B.3.5 Pneumonia in the immunocompromised host

B.3.6 Other pneumonia

B.3.7 Parapneumonic effusion and empyema

B.3.8 Lung abscess

B.3.9 Fungal infection

B.3.10 Parasitic infection

B.3.11 Epidemic viral infection

See also modules: B1.6, B.7, B.8, B.10, B.11, B.12, B.13, B.15, B.16, B.17, B.18, B20

\section{Module B.4: Tuberculosis}

\section{B.4.1 Pulmonary TB}

B.4.2 Extrapulmonary $T B$

B.4.3 TB in the immunocompromised host

B.4.4 Latent tuberculous infection
Optional Mandatory Level $1 \quad$ Level 2 Level 3
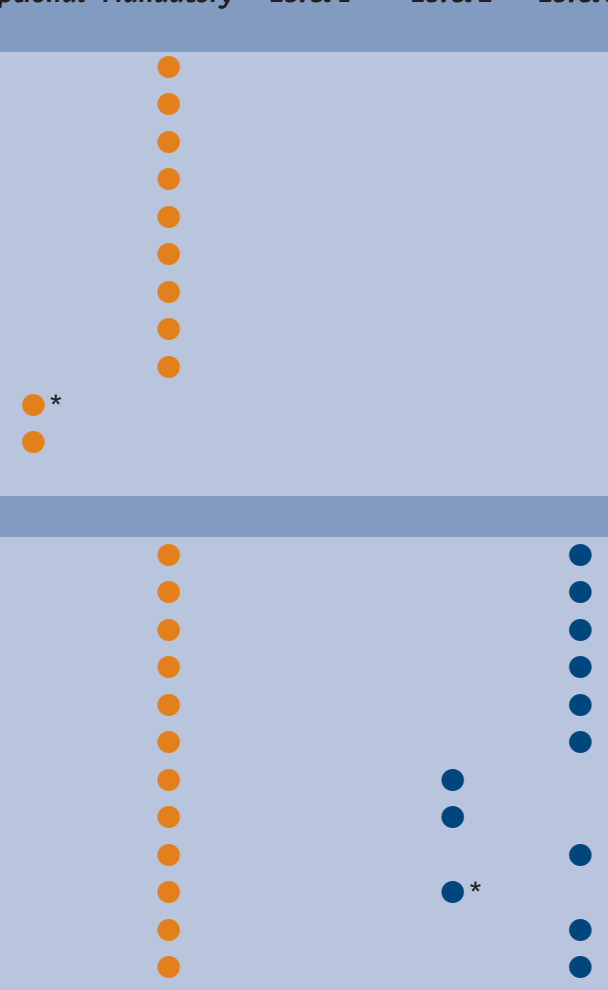
B.4.5 Non-tuberculous mycobacterial diseases

See also modules: B.1, B.6, B.10, B.11, B.12, B.13, B.16, B.20

\section{Module B.5: Pulmonary vascular diseases}

\section{B.5.1 Pulmonary embolism}

B.5.2 Primary pulmonary hypertension

B.5.3 Secondary pulmonary hypertension

B.5.4 Vasculitis and diffuse pulmonary haemorrhage

B.5.5 Abnormal a-v communication

See also modules: B.1, B.7, B.10, B.11, B.14, B.15, B.16

\section{Module B.6: Occupational and environmental diseases}

\section{B.6.1 Occupational asthma}

B.6.2 Reactive airway dysfunction syndrome

B.6.3 Pneumoconiosis and asbestos-related disease

B.6.4 Hypersensitivity pneumonitis

B.6.5 Dust and toxic gas inhalation disease

B.6.6 Indoor pollution related disease

B.6.7 Outdoor pollution related disease

B.6.8 Smoking-related disease

B.6.9 High-altitude disease

B.6.10 Diving-related disease

See also modules: B.1, B.2, B.3, B.4, B.7, B.9, B.10, B.11, B.17, B.18

\section{Module B.7: Diffuse parenchymal (interstitial) lung diseases}

B.7.1 Sarcoidosis

B.7.2 Idiopathic interstitial pneumonias including idiopathic pulmonary fibrosis

(IPF), non-specific interstitial pneumonia (NSIP), cryptogenic organising pneumonia

(COP), acute interstitial pneumonia (AIP), respiratory bronchiolitis-associated

interstitial lung disease (RB-ILD), desquamative interstitial pneumonia (DIP),

lymphoid interstitial pneumonia (LP)

B.7.3 Cryptogenic organising pneumonia (COP) of unknown aetiology/bronchiolitis

obliterans organising pneumonia (BOOP)

See also modules: B.3, B.5, B.6, B.8, B.10, B.14, B.15, B.18, B.19, B.20, B.21

\section{Module B.8: Iatrogenic diseases}

B.8.1 Drug-induced disease

B.8.2 Complications of invasive procedures

B.8.3 Radiation-induced disease

See also modules: B.1, B.3, B7, B9, B10, B11, B12, B13, B14, B17, B19, B.20

Module B.9: Acute injury

\section{B.9.1 Inhalation lung injury}

B.9.2 Traumatic thoracic injury

See also modules: B.1, B.6, B.8, B.10, B.11, B.12, B.13

Module B.10: Respiratory failure

B.10.1 Acute respiratory distress syndrome

B.10.2 Obstructive lung disease

B.10.3 Neuromuscular disease

B.10.4 Chest wall disease

$B .10 .5$ Other restrictive diseases

See also modules: B.1, B.3, B.4, B.5, B.6, B.7, B.8, B.9, B.11, B.12, B.13, B.14, B.15,

B.16, B.17, B.18, B.19, B.20, B.21

Module B.11: Pleural diseases

B.11.1 Pleural effusion

B.11.2 Chylothorax

B.11.3 Haemothorax

B.11.4 Fibrothorax

B.11.5 Pneumothorax

See also modules: B.2, B.3, B.4, B.5, B.6, B.8, B.9, B.10, B.13, B.14, B.15, B.16,

B.19, B.20, B.21

Module B.12: Diseases of the chest wall and respiratory muscles including the diaphragm

B.12.1 Chest wall deformities

B.12.2 Neuromuscular disorders

B.12.3 Phrenic nerve palsy

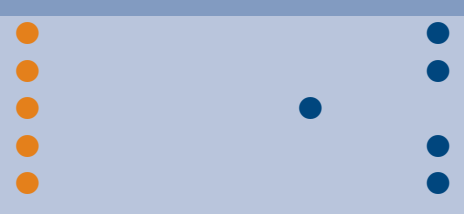


B.12.4 Diaphragmatic hernia

Optional Mandatory Level $1 \quad$ Level 2 Level 3

See also modules: B.2, B.3, B.4, B.8, B.9, B.10, B.14, B.15, B.19

Module B.13: Mediastinal diseases excluding tumours

B.13.1 Mediastinitis

B.13.2 Mediastinal fibrosis

B.13.3 Pneumomediastinum

See also modules: B.2, B.3, B.4, B.8, B.9, B.10, B.11, B.15

Module B.14: Pleuro-pulmonary manifestations of systemic/extrapulmonary disorders

B.14.1 Collagen vascular disease

B.14.2 Cardiac disease

B.14.3 Abdominal disease

B.14.4 Haematological disease

B.14.5 Obesity

B.14.6. Hyperventilation syndrome

See also modules: B.1, B.2, B.5, B.7, B.8, B.10, B.11, B.12, B.16, B.19, B.20

Module B.15: Genetic and developmental disorders

B.15.1 Cystic fibrosis

B.15.2 Primary ciliary dyskinesia

B.15.3 Alpha-1 antitrypsin deficiency

B.15.4 Malformations

See also modules: B.1, B.3, B.5, B.7, B.10, B.11, B.12, B.13, B.16, B.19, B.20, B.21

Module B.16: Respiratory diseases and pregnancy

B.16.1 Asthma

B.16.2 Cystic fibrosis

B.16.3 Tuberculosis

B.16.4 Sarcoidosis

B.16.5 Restrictive lung diseases

B.16.6 Pregnancy-induced respiratory diseases

See also modules: B.1, B.3, B.A, B.5, B.10, B.11, B.14, B.15, B.17, B.19

Module B.17: Allergic diseases (IgE-mediated)

B.17.1 Upper airway disease

B.17.2 Asthma

B.17.3 Bronchopulmonary aspergillosis

B.17.4 Anaphylaxis

See also modules: B.1, B.3, B.6, B.8, B.10, B.16, B.18

Module B.18: Eosinophilic diseases

B.18.1 Non-asthmatic eosinophilic bronchitis

B.18.2 Acute and chronic eosinophilic pneumonia

B.18.3 Hypereosinophilic syndrome

B.18.4 Churg-Strauss syndrome

See also modules: B.1, B.3, B.6, B.7, B.10, B.17

Module B.19: Sleep-related disorders

B.19.1 Obstructive sleep apnoea syndrome

B.19.2 Central sleep apnoea syndrome

B.19.3 Obesity hypoventilation syndrome

See also modules: B.1, B.7, B.8, B.10, B.11, B.12, B.14, B15, B16

Module B.20: Immunodeficiency disorders

B.20.1 Congenital immunodeficiency syndrome

B.20.2 Acquired immunodeficiency syndrome

B.20.3 HIV-related disease

B.20.4 Drug-induced disease

B.20.5 Graft versus host disease

B.20.6 Post-transplantation immunodeficiency

See also modules: B.1, B.3, B.4, B.7, B.8, B.10, B.11, B.14, B.15

Module B.21: Orphan lung diseases

B.21.1 Langerhans' cell histiocytosis

B.21.2 Lymphangioleiomyomatosis (LAM)

B.21.3 Pulmonary alveolar proteinosis

B.21.4 Amyloidosis

See also modules: B.1, B.7, B.10, B.11, B15 


\begin{tabular}{|c|c|c|c|c|c|}
\hline \multicolumn{6}{|l|}{ Module C.1: Symptoms and signs } \\
\hline C.1.1 Dyspnoea & & 0 & & & \\
\hline C.1.2 Wheeze & & 0 & & & \\
\hline C.1.4 Hoarseness & & 0 & & & \\
\hline C.1.5 Cough & & 0 & & & \\
\hline C.1.6 Sputum production & & 0 & & & \\
\hline C.1.9 Snoring & & - & & & \\
\hline $\begin{array}{l}\text { C.1.10 General symptoms of disease including fever, weight loss, oedema, nocturia, and } \\
\text { daytime somnolence }\end{array}$ & & 0 & & & \\
\hline $\begin{array}{l}\text { C.1.11 Abnormal findings on inspection including cyanosis, abnormal breathing patterns, } \\
\text { finger clubbing, chest wall deformities, superior vena cava syndrome and Horner's syndrome }\end{array}$ & & 0 & & & \\
\hline C.1.12 Abnormal findings on palpation and percussion & & 0 & & & \\
\hline D.1.2 Body plethysmography-interpretation & & 0 & & & ○ \\
\hline D.1.3 Gas transfer- interpretation & & 0 & & & ? \\
\hline D.1.4 Blood gas assessment and oximetry-interpretation and performance & & 0 & & & - \\
\hline D.1.5 Bronchial provocation testing-interpretation and performance & & - & & & ○ \\
\hline $\begin{array}{l}\text { D.1.6 Exercise testing including walking tests and spiroergometry (cardio-pulmonary exercise } \\
\text { testing)- interpretation and performance }\end{array}$ & & - & & & ? \\
\hline D.1.7 Assessment of respiratory mechanics- interpretation & & 0 & & & ○ \\
\hline D.1.8 Compliance measurements- interpretation & & 0 & & * & \\
\hline D.1.9 Respiratory muscle assessment-interpretation & & 0 & & * & \\
\hline D.1.10 Ventilation-perfusion measurement- interpretation & & - & & & ○ \\
\hline D.1.11 Shunt measurement-interpretation & & 0 & & * & \\
\hline D.1.12 Sleep studies- interpretation and performance & & 0 & & & - \\
\hline D.2.6 Allergy skin testing & & 0 & & & 0 \\
\hline D.2.7 Pleural ultrasound imaging & & O & & & 0 \\
\hline D.2.8 Thoracentesis & & - & & & ○ \\
\hline D.2.9 Closed pleural needle biopsy & & 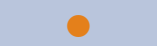 & & & 0 \\
\hline D.2.10 Pleuroscopy (medical thoracoscopy) & & 0 & & 0 & \\
\hline D.2.11 Flexible bronchoscopy & & 0 & & & 0 \\
\hline D.2.12 Transbronchial lung biopsy & & 0 & & & 0 \\
\hline D.2.13 Transbronchial needle aspiration & & 0 & & & 0 \\
\hline D.2.14 Endobronchial ultrasound & * & & & ○ & \\
\hline D.2.15 Broncho-alveolar lavage & & 0 & & & ○ \\
\hline D.2.16 Bronchography & - & & & ○ & \\
\hline D.2.17 Rigid bronchoscopy & - & & & ( & \\
\hline $\begin{array}{l}\text { D.2.18 Interventional bronchoscopic techniques including fluorescence bronchoscopy, } \\
\text { brachytherapy, endobronchial radiotherapy, afterloading laser and electrocoagulation } \\
\text { cryotherapy, photodynamic therapy, airway stents }\end{array}$ & 0 & & & 0 & \\
\hline D.2.19 Percutaneous needle biopsy & & 0 & & & ? \\
\hline D.2.20 Fine needle lymph node aspiration for cytology & & 0 & & & 0 \\
\hline D.2.21 Right heart catheterisation & 0 & & & ? & \\
\hline D.2.22 Chest X-ray & & - & & & ○ \\
\hline D.2.23 Fluoroscopy & & 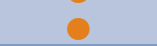 & & ○ & \\
\hline \multicolumn{6}{|l|}{ Module D.3: Procedures performed collaboratively } \\
\hline D.3.1 Thoracic imaging (X-ray, CT, MRI) & & - & & & ○ \\
\hline D.3.2 Nuclear medicine techniques (pulmonary and bone scan PET) & & 0 & & ○ & \\
\hline
\end{tabular}


D.3.4 Echocardiography

D.3.5 Ultrasound

D.3.6 Transoesophageal ultrasound

D.3.7 Oesophageal $\mathrm{pH}$ monitoring

D.3.8 Cytology/histology

D.3.9 Microbiology testing

Module E.1: Treatment modalities and prevention measures

E.1.1 Systemic/inhaled drug therapy

E.1.2 Chemotherapy

E.1.3 Other systemic anti-tumour therapy

E.1.4 Immunotherapy including de-/hyposensitisation

E.1.5 Oxygen therapy

E.1.6 Ventilatory support (invasive/non-invasive/CPAP)

E.1.7 Cardiopulmonary resuscitation

E.1.8 Assessment for anaesthesia/surgery

E.1.9 Endobronchial therapies

E.1.10 Intercostal tube drainage

E.1.11 Pleurodesis

E.1.12 Home care

E.1.13 Palliative care

E.1.14 Pulmonary rehabilitation

E.1.15 Nutritional interventions

E.1.16 Surfactant therapy

E.1.17 Gene therapy

E.1.18 Principles of stem cell therapy

E.1.19 Smoking cessation

E.1.20 Vaccination and infection control

E.1.21 Other preventative measures

Module F: Core generic abilities

F.1 Communication including patient education and public awareness

F.2 Literature appraisal

F.3 Research

F.4 Teaching

F.5 Audit/quality assurance of clinical practice

F.6 Multidisciplinary teamwork

F.7 Administration and management

F.8 Ethics

Module G: Competence in fields shared with other specialties

G.1 Intensive care

G.2 High-dependency unit (HDU)

Module H: Knowledge of associated fields relevant to adult respiratory medicine

H.1 Thoracic surgery (including lung transplantation)

H.2 Radiotherapy

H. 3 Paediatric respiratory medicine

H. 4 Chest physiotherapy

H. 5 Other relevant medical specialties

Module I: Further areas relevant to respiratory medicine

I.1 Epidemiology

I.2 Statistics

I.3 Evidence-based medicine

I.4 Quality of life measures

I.5 Psychological factors in the development of respiratory disease

I. 6 Psychological consequenses of chronic respiratory disease

I.7 Public health issues

I.8 Organisation of healthcare across Europe

I.9 Economics of healthcare across Europe

I.10 Compensation and legal issues
Optional Mandatory Level 1

Level 2

Level 3

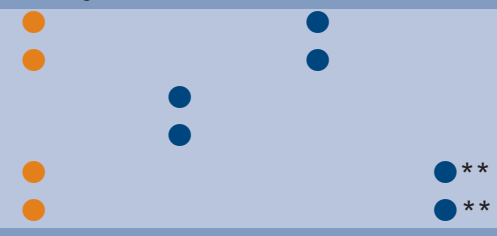

0
0
0
0
0
0
0
0
0
0
0
0
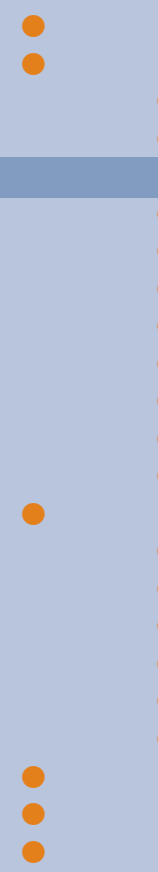

0

-

-

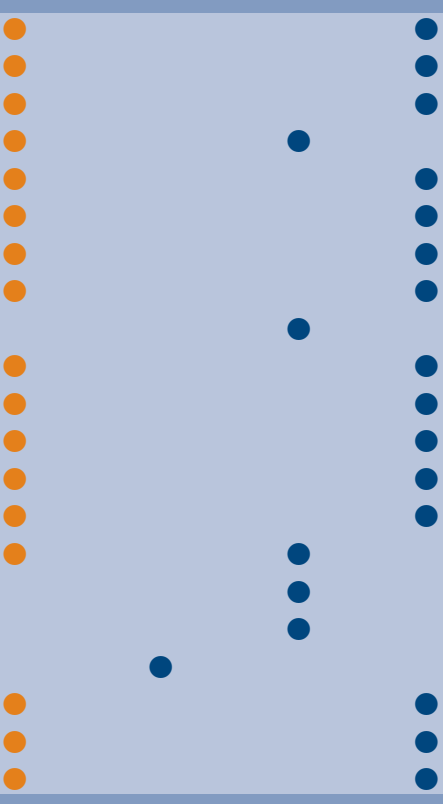

*: the task force feels these items should be re-evaluated in the near future; **: the task force has rephrased these items, and adapted their levels of competence accordingly. 